\title{
SINKHOLES AS TRANSPORTATION AND INFRASTRUCTURE GEOHAZARDS IN MIXED EVAPORITE-SILICICLASTIC BEDROCK, SOUTHEASTERN NEW MEXICO
}

\author{
Lewis Land \\ National Cave and Karst Research Institute, 400-1 Cascades Ave., Carlsbad, NM, 88220 USA, lland@nckri.org
}

\section{Colin Cikoski}

New Mexico Bureau of Geology and Mineral Resources, 801 Leroy Pl., Socorro, NM, 87801 USA, colin.cikoski@nmt.edu

\section{George Veni}

National Cave and Karst Research Institute, 400-1 Cascades Ave. Carlsbad, NM, 88220 USA, gveni@nckri.org

\begin{abstract}
Personnel with the National Cave and Karst Research Institute and the New Mexico Bureau of Geology and Mineral Resources conducted an assessment of karst geohazards southeast of Carlsbad, New Mexico, USA. The US Highway 285 corridor in this area is subject to high levels of oilfield traffic, and is particularly prone to sinkholes because of the presence of gypsum bedrock of the Rustler Formation at or near the surface throughout much of the study area. These features pose a geohazard for the transportation and pipeline network in this part of the state. The geotechnical properties of the Rustler Formation are influenced by soluble gypsum strata interbedded with mechanically weak mudstone and siltstone and more rigid dolomite beds. Surface geologic mapping and near-surface electrical resistivity (ER) surveys indicate that most sinkholes formed in the Rustler are relatively shallow $(<3 \mathrm{~m})$, without deep roots, probably due to the mixed lithology of soluble and insoluble bedrock. However, longer-array ER surveys have identified additional cavities at greater depths that do not breach the surface.
\end{abstract}

\section{Background}

On October 9, 2015 the New Mexico Department of Transportation (NMDOT) reported that a sinkhole had opened on the east shoulder of US Highway 285 south of the village of Malaga, New Mexico, about $16 \mathrm{~km}$ north of the Texas/New Mexico state line (Figure 1). This sinkhole is approximately two meters in diameter and 1.5 meters deep, and is less than six meters from the edge of the roadway, within the highway right-of-way. Because of nearby oil and gas activity, there is a substantial amount of traffic along this portion of US 285, including large trucks.
The sinkhole thus poses a hazard to the travelling public. Surface geologic maps indicate that bedrock of the upper Permian Rustler Formation is present at or near the surface beneath US 285 from Malaga south to the state line, and crops out within six meters of the new sinkhole. The Rustler is composed in part of highly soluble gypsum, thus making it prone to sinkhole formation. Sinkholes are widespread in outcrops of the Rustler Formation and associated upper Permian evaporites in the lower Pecos Valley (e.g., Kelley, 1971). Because of the poor condition of the existing roadbed, NMDOT has proposed construction of a highway realignment $\sim 20$ meters west of the existing highway, extending about $35 \mathrm{~km}$ from the state line to the community of Loving, New Mexico (Figure 1).

During an eight-month period from November 2016 through June 2017, personnel with the National Cave and Karst Research Institute (NCKRI) and the New Mexico Bureau of Geology and Mineral Resources (NMBGMR) conducted surface reconnaissance, geologic mapping, and near-surface geophysical surveys of the US 285 right-ofway (NCKRI and NMBGMR, 2016). The initial phase of the investigation involved walking the entire route from the Texas state line to the outskirts of Loving (Figure 1). Sinkholes and other karst features were recorded and the geology mapped. In November 2016 two electrical resistivity (ER) surveys were conducted adjacent to the sinkhole $16 \mathrm{~km}$ north of the state line that had generated the initial interest in this investigation. In March through June 2017 NCKRI and NMBGMR personnel conducted additional ER surveys of selected sinkholes and other karst geohazards that had been identified as potentially high-risk features during the previous year's surface reconnaissance mapping. 

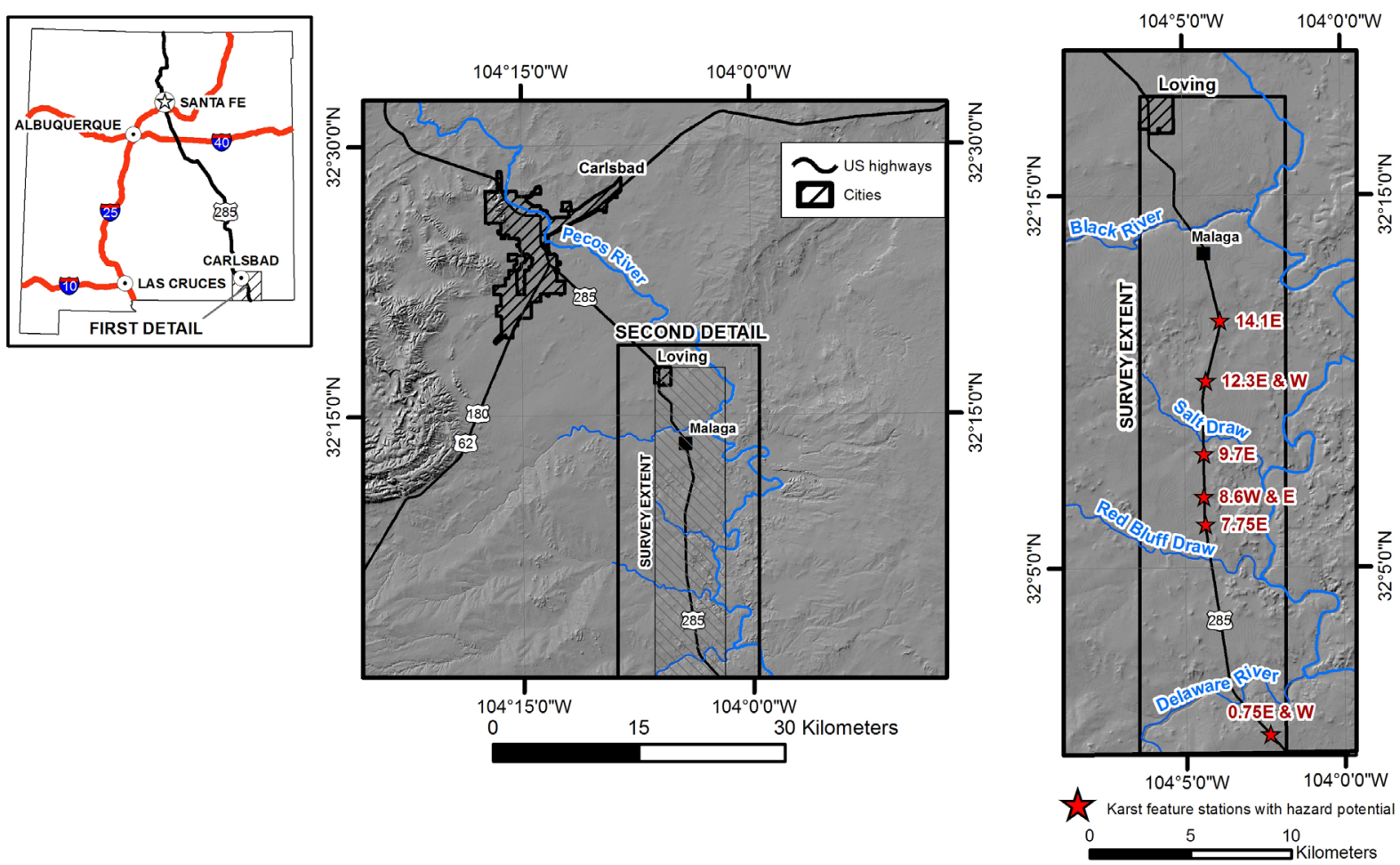

Figure 1. Location of study area and sites with estimated karst hazard potential. The sinkhole that initiated interest in this investigation is located at Station 9.7E.

\section{Geologic Setting}

The study area lies in the Pecos River Valley of southeastern New Mexico, on the northern flank of the Delaware Basin. Bedrock in the area consists of upper Permian evaporitic rocks of the Ochoan series, including the Castile, Salado, and Rustler Formations; and non-marine sands and mudstones of the Tertiary Gatuña Formation (Figure 2; Kelley, 1971). Only the lowest two members of the Rustler Formation, the Los Medaños and the Culebra Dolomite, crop out along US 285 in the study area. The lower of these, the Los Medaños, consists of up to $36 \mathrm{~m}$ of mudstones grading upsection to interbedded mudstones, anhydrite and/or gypsum, and halite (Bachman, 1980; Powers, 1997). The overlying Culebra Dolomite consists of 8 to $10 \mathrm{~m}$ of thinly bedded ledge-forming dolomite (Bachman, 1980). Where occurring at the surface, the Culebra commonly caps low knolls surrounded by swales underlain by gypsiferous Los Medaños outcrops. Locally, the Culebra forms low structural domes tens to hundreds of meters in diameter, where the dolomite beds dip radially outward from a central point. Very locally, outcrops of the Culebra are internally brecciated. Bachman (1980) interpreted both the structural domes and local breccia as products of dissolution of salts from underlying strata causing localized subsidence or collapse of the Culebra into underlying karst features.

The Gatuña Formation consists of lenticular sandstones, mudstones, and thin beds of crystalline gypsum that accumulated in alluvial settings. It contains $\sim 13$ and 0.6 Ma volcanic ashes (Powers and Holt, 1993) and is typically capped by calcretes which range in age from several million years to $\sim 0.5 \mathrm{Ma}$ (Hawley, 1993). Cather (2011; 2016, personal communication) recognizes two main lithofacies: an axial fluvial facies and intercalated alluvial deposits of local transverse drainages containing eolian sandsheet beds. The Gatuña outcrops within the study site fall within this latter "piedmont" facies, comprised of reddish-brown mudstones with lesser lenticular sandstone beds. These are poorly exposed and crop out irregularly in road cuts along US 285, commonly capped by Quaternary alluvial gravels. Bedding measurements in most exposures have moderate dips $\left(15\right.$ to $\left.50^{\circ}\right)$ and dip directions are inconsistent, locally directed toward the east, southeast, west, and north. Similarly inconsistent moderate dips in the Gatuña in the region have been interpreted as evidence for karstrelated subsidence by Kelley (1971) and Powers and Holt (1993). Thickness of the Gatuña in the study area 


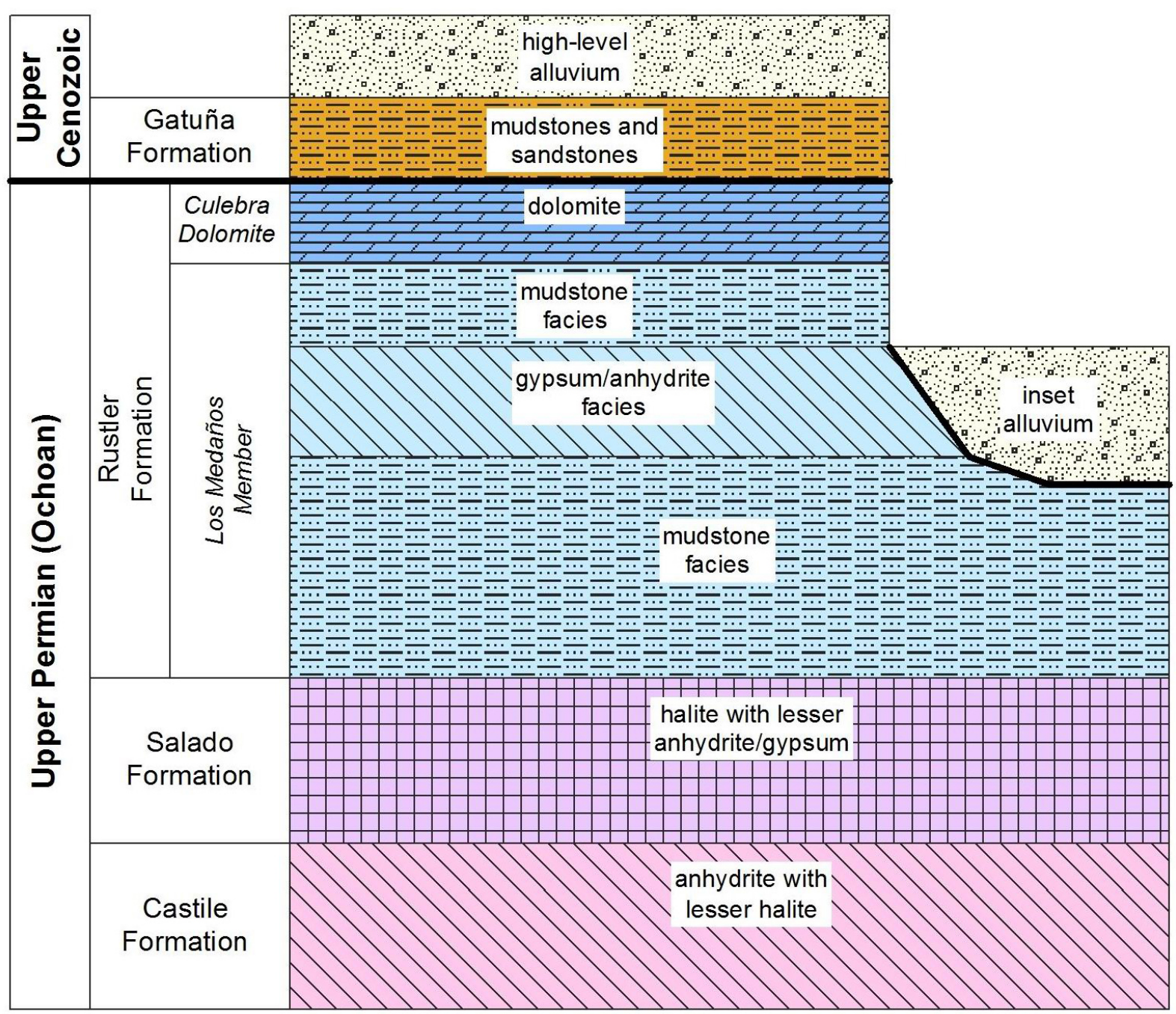

Figure 2. Upper Permian (Ochoan) stratigraphy of study area.

is highly variable, ranging up to $\sim 90 \mathrm{~m}$. Powers and Holt (1993) report that measurable outcrops are commonly 9 to $30 \mathrm{~m}$ thick, although a basal contact is not present at many exposures.

Several ages of Quaternary alluvium either cap or are inset into the Rustler and Gatuña Formations. The oldest alluvial deposits underlie the broad high-level plains found between major streams and are composed chiefly of gravels. Younger terrace deposits occur along the flanks of major streams inset against the high-level plains, and are composed mainly of sands and muds with lesser gravels. Alluvial deposits are zero to at least eight $m$ thick in the study area.

The regional structure is dominantly a low-gradient, eastward-dipping homocline (Bachman, 1987). Several broad east-northeast-trending synclines and anticlines can be inferred to affect the Rustler Formation based on structure contours compiled by Hiss (1976). These folds may be solution-subsidence troughs caused by subsidence into linear bands of preferential dissolution in the underlying Salado Formation (NCKRI and NMBGMR, 2017). Additionally, the erratic dip directions of Gatuña Formation beds may be the product of local dissolutionrelated subsidence. Sinkholes mapped during this study may be concentrated along at least one of these solutionsubsidence troughs (NCKRI and NMBGMR, 2017). No mapped faults cross the study area, and no evidence of faulting was observed during this study.

The most important water-bearing unit within the Rustler Formation is the Culebra dolomite (Hendrickson and Jones, 1952), within which water is present in perched aquifers above low-permeability gypsum and mudstone lithologies of the Los Medaños Member, and underlying 
halite and anhydrite beds of the Salado and Castile Formations (Figure 2). A well-defined and continuous shallow water table is not present in the survey area.

\section{Methods Surface Reconnaissance}

Exploration for sinkholes, caves, and other karst features was conducted with teams of two to four people walking no more than $\sim 15 \mathrm{~m}$ apart and generally parallel to the highway. This reconnaissance work was guided and supplemented by air photo imagery provided by the contractor. Most karst features within an area can be discovered with this spacing, although some small features (less than $\sim 10 \mathrm{~cm}$ diameter and/or $<5 \mathrm{~cm}$ deep) with little surface expression may still be missed. Discovered features were marked with small, engraved aluminum tags and long strips of red and white survey tape, with their identification numbers marked on the tape in waterproof ink. The locations of newly discovered karst features were measured with Universal Transverse Mercator (UTM) coordinates captured with hand-held global positioning system (GPS) receivers. Geologic contacts and outcrops were also similarly identified and located during this survey, with all of the data later processed by geographic information system (GIS) software for display and spatial analysis. Field evaluations included depth and lateral dimensions of sinkholes, lithology, measurement of fractures, and observations of flow features, sediment, water flow, and air flow. This information was recorded on forms designed for such surveys, and with a scaled sketch of each feature, including a plan view and profile.

Data from the forms were placed into an Excel spreadsheet designed to quantitatively predict which karst features pose the greatest potential risk of collapse or subsidence. The general method was discussed and successfully applied by Veni (1999). Per that method, the spreadsheet was adjusted to the local geology after weighing factors such as limestone vs. gypsum bedrock, predominant mode of cave development and morphology, preferential fracture orientations along which large and potentially unstable caves are more likely to develop, and related factors that may further suggest structural stability or instability of karstic cavities. The characteristics of each karst feature were tallied with point values commensurate with the significance of each characteristic in demonstrating its potential for collapse or subsidence. All non-karst features were classified as artificial. The sum of the assigned point values is multiplied by a point value assigned to the feature type. Based on experience and comparison with related karst features in this and other areas, the significance of a feature is ranked as no potential risk for 0 points, low potential risk for 1-150 points, moderate potential risk for 151-250 points, and high potential risk for $>250$ points. These ranks were color coded and the features plotted on a geologic map that was created from the field survey, allowing prioritized selection of areas for geophysical investigation.

\section{Geophysical Surveys}

Electrical resistivity surveys are a common and effective geophysical method for detection of subsurface voids (e.g., Land and Veni, 2012; Land, 2013; Land and Asanidze, 2015). The basic operating principal for an ER survey involves generating a direct current between two metal electrodes implanted in the ground, while measuring the ground voltage between two other implanted electrodes. Given the current flow and voltage drop between the electrodes, differences in subsurface electrical resistivity can be determined and mapped. Modern resistivity surveys employ an array of multiple electrodes connected with electrical cable. Over the course of a survey, pairs of electrodes are activated by means of a switchbox and resistivity meter. The depth of investigation for a typical ER survey is approximately one-fifth the length of the array of electrodes.

Resistivity profiles illustrate vertical and lateral variations in subsurface resistivity. The presence of water or water-saturated soil or bedrock will strongly affect the results of a resistivity survey. Air-filled caves or air-filled pore space in the vadose zone are easy to detect using the ER method, because air has near-infinite resistivity, in contrast with 10 to 15 orders of magnitude more conductive surrounding bedrock.

A SuperSting R8/IP electrical resistivity system provided by Advanced Geosciences, Inc. (AGI) was used to collect resistivity data, employing a dipole-dipole array configuration. All of the ER surveys conducted in March, April, and May 2017 used a 42 electrode array at one meter electrode spacing, for a target depth of investigation of $\sim 10$ meters. Rollalong methods were used at some sites to extend the length of the survey lines. After data were collected using the initial array of electrodes, the lower half of the array was shifted forward 
to the far end for a $50 \%$ overlap. In some survey areas, multiple rolls were employed. Although this method does not increase the depth of investigation, it permits a seamless ER profile much longer than the length of the main array. Additional ER surveys of bridges and bridge abutments, conducted in June 2017, employed 56 electrode arrays at three meter electrode spacing for a target exploration depth of $\sim 33$ meters.

While resistivity data were collected, a Topcon GR3 GPS instrument package was used to collect surveygrade GPS coordinates for each electrode in the arrays. Elevation data collected during these surveys were used to correct the resistivity data for variations in topography at each survey site. ER data were processed using EarthImager-2D ${ }^{\mathrm{TM}}$ software. The EarthImager software chooses a resistivity scale designed to highlight natural conditions in the subsurface, thus resistivity profiles from different survey areas may not have the same resistivity scale. AGI technical staff report that, in general, it is not advisable to force the software to adhere to a specific scale, and attempts to do so may yield misleading results.

High resistivity anomalies may represent either void space in the subsurface (caves or potential sinkholes), or brecciated/leached zones in gypsum bedrock with air-filled pore space. Laterally continuous layers of high or low resistivity may reflect near-surface stratigraphy, such as gypsum or dolomite beds (generally higher resistivity), or mudstone/shale layers (lower resistivity) in the Los Medaños; or interbedded finer- and coarsergrained sediments in alluvial deposits. Very near-surface high resistivity layers often result from air-filled porosity in soil or weathered bedrock. Areas of medium resistivity may reflect sediment-filled voids.

\section{Results}

Six specific areas were identified with a high estimated hazard potential based on surface geologic mapping, quantitative evaluation of karst features, and electrical resistivity surveys (Figure 3). The southernmost area is located about $1.2 \mathrm{~km}$ from the Texas state line. The remaining five potential hazard areas are located between 12 and $23 \mathrm{~km}$ north of the state line. All of these sites are located in areas where the gypsiferous Los Medaños member of the Rustler Formation crops out or is present within one meter of the surface, consistent with the soluble nature of that lithology. Three of these sites are discussed below.
Where surface karst features are present within five meters of the survey line, their positions are projected onto the resistivity profiles and indicated by black bars. Individual resistivity surveys discussed below are labelled according to their proximity to specific karst features identified during the surface reconnaissance.

\section{Station 7.75E}

Three large sinkholes ( $>3 \mathrm{~m}$ diameter, $1.5 \mathrm{~m}$ deep) were identified at this site, formed in Quaternary sediment underlain by gypsum bedrock, which is exposed at the bottom of the sinkholes. These features occur in a broad swale on both sides of the right-of-way fence. An ER survey was conducted west of two of the sinkholes, and skirted one large sinkhole on the west side of the fence. The latter feature shows up clearly as a high resistivity anomaly between $\sim 50$ to 55 meters on the profile (Figure 4). An elongate depression on the east side of the fence with a deep sinkhole at the south end roughly coincides with a zone of moderate to high resistivity between 25 to 35 meters on the ER profile. A borehole drilled by the contracting agent, projected onto the survey line at 30 meters, encountered a possible cavity at 2.3 meters below ground level (bgl). Given the size of the sinkholes at this site, it is interesting to note that none of the high resistivity anomalies extend more than 5 meters bgl.

\section{Station $8.6 \mathrm{~W}$}

This site has a very high concentration of sinkholes over a distance of about 76 meters, some of which may be cave entrances (Figure 5), formed in soil and gypsum bedrock on the eastern edge of a broad, shallow $(<1$ meter deep) subsidence depression.

An ER survey was conducted at Station 8.6W with the array of cable deployed between and immediately adjacent to most of the sinkholes. The ER profile shows some high resistivity anomalies that coincide with the surface features (Figure 6). However, none of the anomalies extend more than three meters beneath the surface, possibly due to a layer of insoluble mudstone underlying the gypsum beds, indicated by a layer of more conductive material (blue shading) on the profile. The north end of the survey line passes directly over two sinkholes, as can be seen on the topographic profile, yet those features are not indicated in the ER survey data. Thus, in spite of the abundance of surface features, these sinkholes do not appear to have deep roots. 

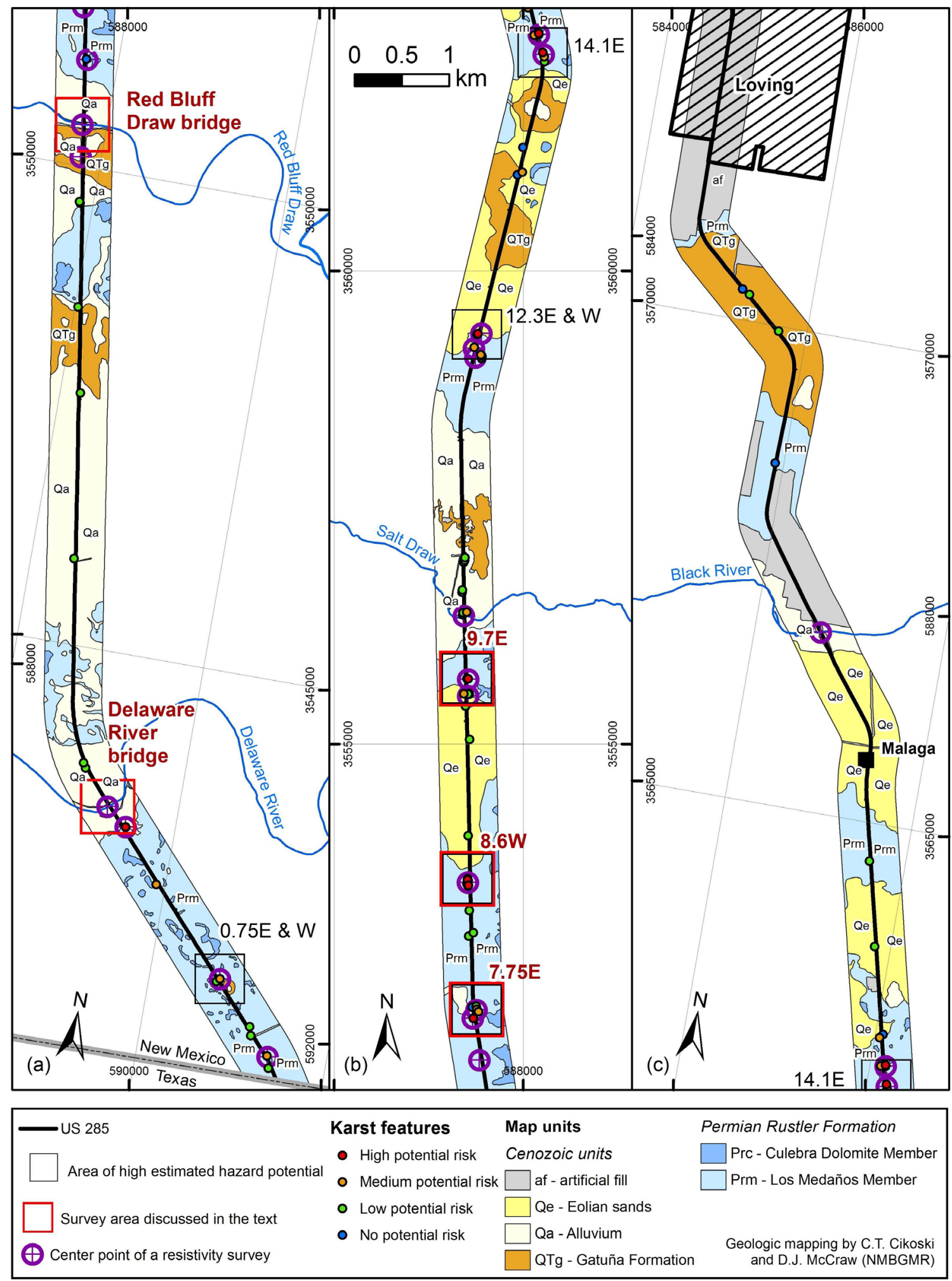

Figure 3. Geologic and geohazards map of survey area, showing locations of sites identified as having high estimated hazard potential. Station numbers are based on highway distance in miles, roughly north from the state line. $E$ and $W$ refer to the relative position of a station east or west of the highway at the given mileage. 
S

US $285-7.75 E$

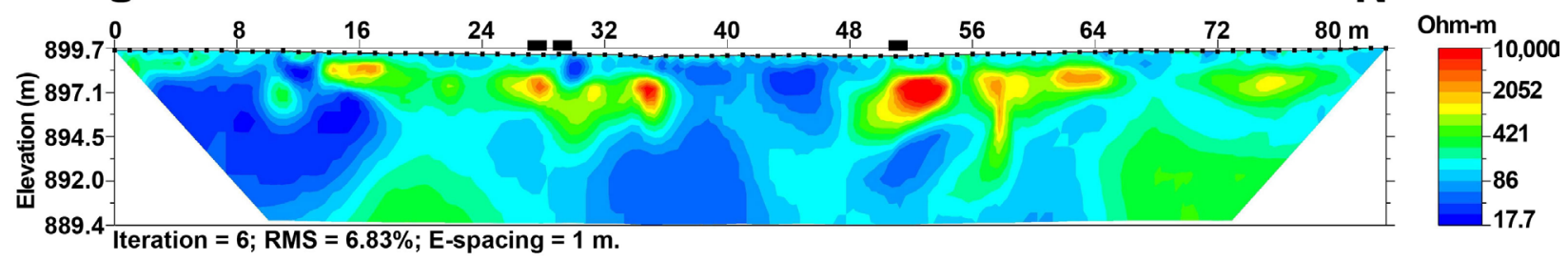

Figure 4. ER profile at station 7.75E. Sinkhole locations are projected onto the survey line and shown by black bars.

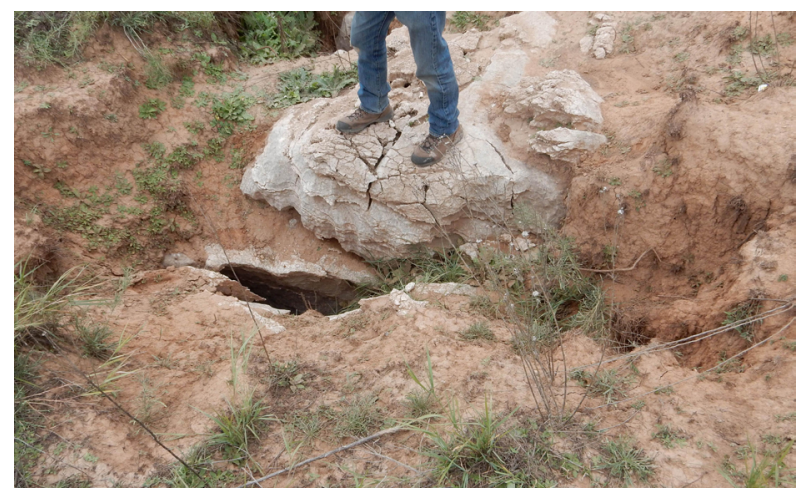

Figure 5. Sinkhole with possible cave entrance, station 8.6W. First author's legs for scale.

\section{Station 9.7E}

This station includes the sinkhole originally identified by NMDOT in 2015 (Figure 7), plus two additional sinkholes formed in gypsum bedrock that crops out within six meters of the original sinkhole. One of the sinkholes may be the entrance to a small cave but is not enterable by humans. Additional sinkholes are present $\sim 6$ meters east of the survey line on the east side of the right-of-way fence.

Two resistivity surveys were conducted at this site. The first survey used a 42 electrode array extended with one 28 electrode roll, for a total of 70 electrodes at one meter spacing, and a target exploration depth of 11 meters (Figure 8A). The ER survey line passes two meters east of the possible cave entrance formed in gypsum bedrock at 35 meters on the profile. That feature is represented by a shallow (one to three meters deep) zone of high resistivity that extends laterally from $\sim 20$ to 38 meters. The high ER anomaly connects to a deeper zone of high resistivity at the south end of the profile, $\sim 6$ meters bgl, indicating the presence of either a subsurface cavity or brecciated zone within Rustler gypsum. In contrast to most of the other sites surveyed, the surface karst features identified at station 9.7E appear to extend deeper into the subsurface.

The second survey used 112 electrodes at six meter spacing, and achieved an exploration depth of 125 meters (Figure 8B). The array for this survey is centered on the shorter array, which is shown in Figure $8 \mathrm{~B}$ by a red bar. The shallow karst features imaged on the 70 electrode survey are still visible as near-surface high resistivity anomalies. This survey also shows a pod of moderately high resistivity ( $2000-5000$ ohm-m) near the center of the profile $\sim 50$ meters bgl, which may indicate the presence of a filled cavity or brecciated zone at greater depth.

\section{Bridge Surveys}

Two long-array ER surveys were conducted on both sides of the Delaware River bridge, perpendicular to the stream valley, using 56 electrode arrays at three meter spacing, and achieving a depth of investigation of $\sim 40$ meters, seven meters greater than the original estimated exploration depth of 33 meters (Figure 9). The survey on the northeast side of the bridge was shortened by 33 meters because of a dense stand of mesquite

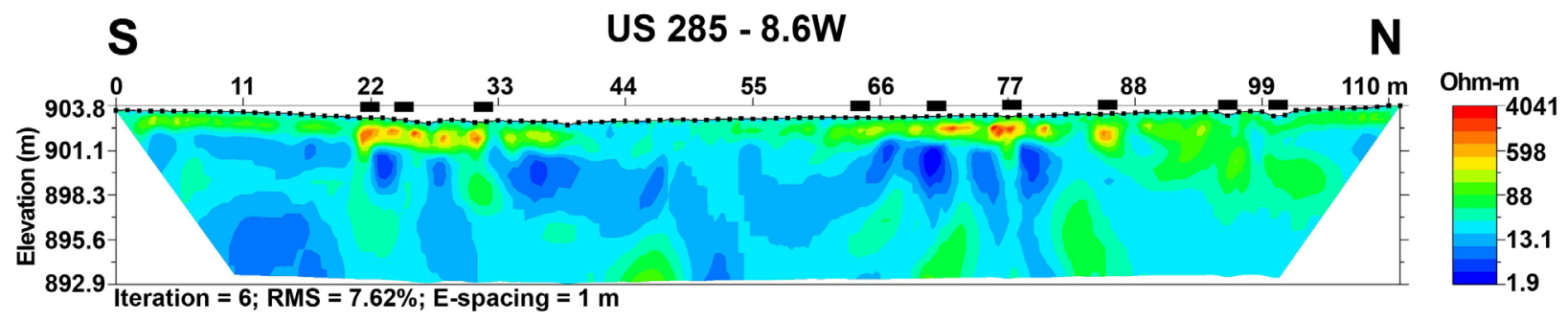

Figure 6. ER profile at station $8.6 \mathrm{~W}$. Sinkhole locations are projected onto the survey line and shown by black bars. 


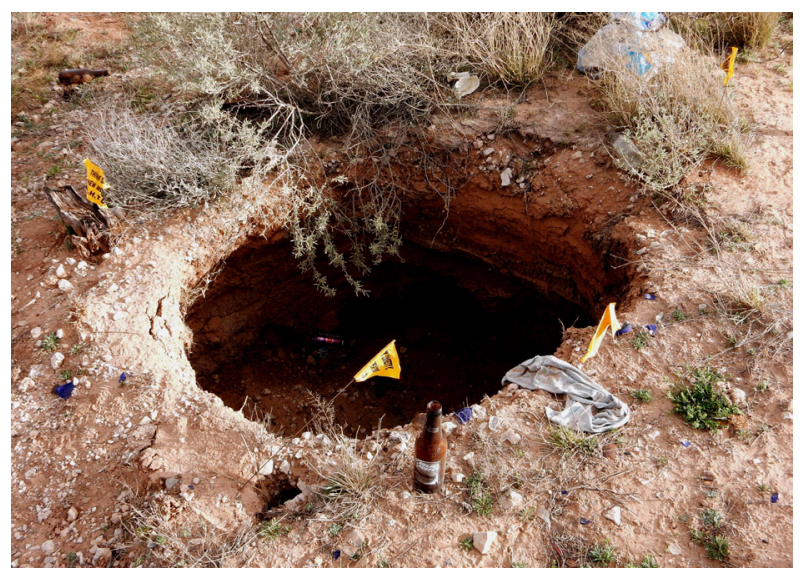

Figure 7. Sinkhole at station 9.7E. Beer bottle for scale.

blocking the survey line. The ER profiles for the most part show moderate to low resistivity material $(<3000 \mathrm{ohm}-\mathrm{m})$, with no evidence of deeper-seated cavities or other karst geohazards. However, an interesting feature of both profiles is an indication of more generally resistive material on the northwest side of the river valley. This phenomenon may reflect differences in the bedrock weathering profile of the Los Medaños gypsum. Surface geologic mapping (Figure 3) indicates that a more extensive alluvial cover as well as older alluvial deposits are present northwest of the Delaware River than is observed to the southeast. This distribution of alluvial material suggests that the Delaware
River may have previously flowed along a trend farther to the northwest of its current location. At that time, leakage from the river could have preferentially weathered the gypsum bedrock, resulting in a lower-density lithology and thus higher electrical resistivity. Although speculative, this model would explain some of the variations in bedrock resistivity observed during this investigation.

Buried anthropogenic material provided ground truth for some of the bridge surveys along the Highway 285 corridor. ER surveys conducted at the base of the north and south bridge abutments at Red Bluff Draw show broad zones of very conductive material $(<3 \mathrm{ohm}-\mathrm{m})$ beneath the bridge $\sim 6$ meters bgl extending beneath the entire bridge (Figure 10). Engineering drawings indicate that a buried concrete apron is present at the base of the north and south bridge abutments. The low resistivity zones on the ER profiles probably result from electrically conductive iron reinforcing rods embedded in the concrete apron.

Long-array ER surveys were also conducted on both sides of Red Bluff Draw bridge, perpendicular to the stream valley, achieving a depth of investigation of $\sim 38$ meters. These surveys extended parallel to each side of the bridge across the entire valley of Red Bluff Draw.

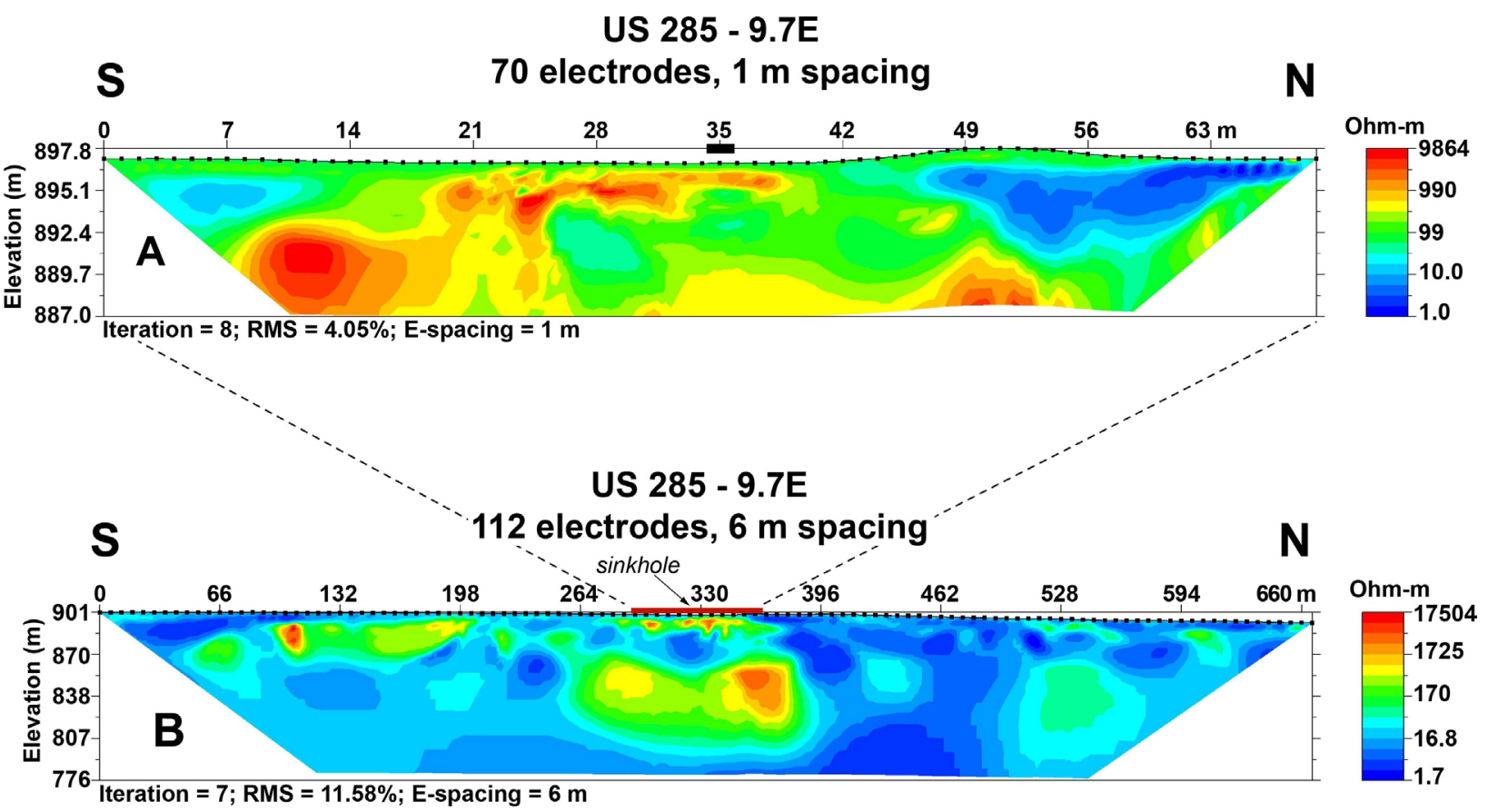

Figure 8. A. ER profile at station 9.7E, 70 electrodes; electrode spacing $=1$ meter. Sinkhole location projected onto survey line and shown by black bar. B. ER profile at station 9.7E, 112 electrodes, electrode spacing $=6$ meters. Position of the 70 electrode profile with respect to the 112 electrode profile is shown by a red bar in $B$. 


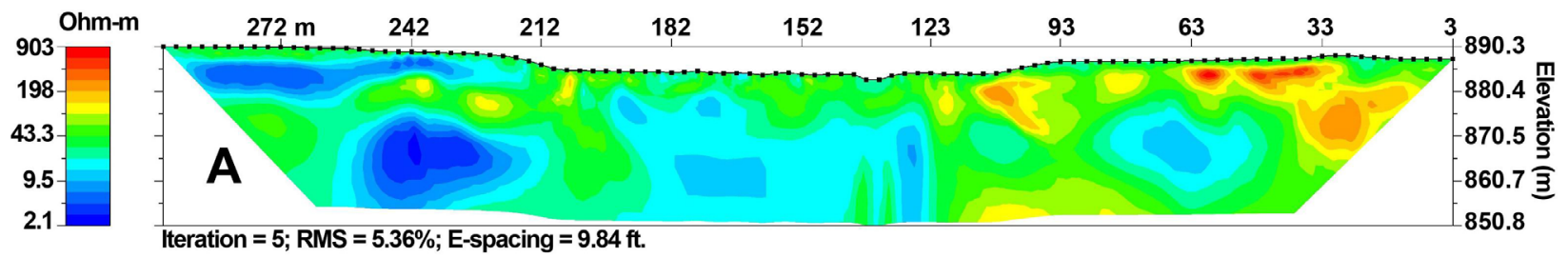

\section{SE}

Delaware River Bridge:

deep profile, southwest side

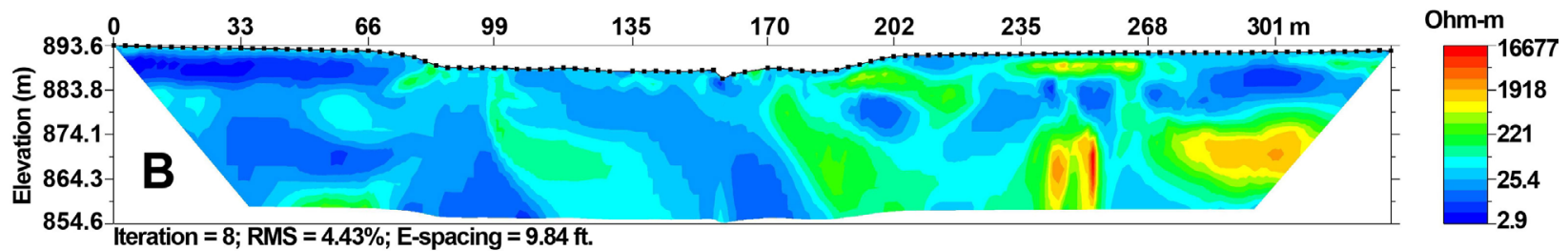

Figure 9. A. Deep profile, northeast side of Delaware River bridge. B. Deep profile, southwest side of Delaware River bridge.

The east side profile of Red Bluff Draw bridge shows a distinct zone of higher resistivity $(>70,000$ ohm-m) beneath the south abutment, $\sim 25$ meters bgl (Figure 11). The west side profile shows a resistivity anomaly of similar size beneath the south abutment at about the same depth (Figure 12). A second ER anomaly is present on the west side profile at $\sim 18$ meters bgl beneath the stream bed, centered at
$95 \mathrm{~m}$. These features probably indicate subsurface cavities formed in gypsum bedrock that do not breach the surface.

\section{Summary}

Six specific areas have been identified in the study area with a high estimated sinkhole hazard potential based on surface geologic mapping and electrical resistivity

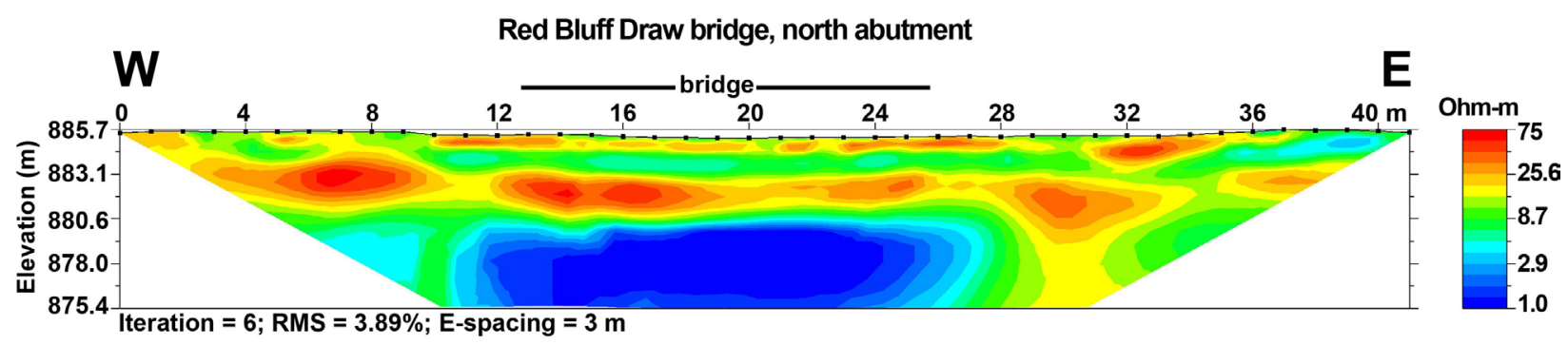

Figure 10. ER survey conducted below Red Bluff Draw bridge, base of north abutment. Position of bridge shown by black bar. Broad zone of electrically conductive material (blue shading) reflects the presence of a buried concrete apron containing iron reinforcing rods at the base of the abutment.

\section{Red Bluff Draw Bridge:} deep profile, east side

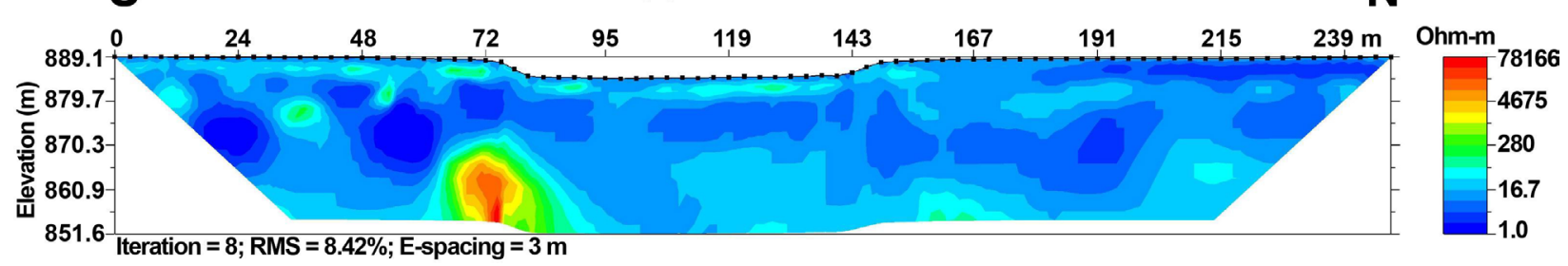

Figure 11. Deep profile, east side of Red Bluff Draw bridge. 


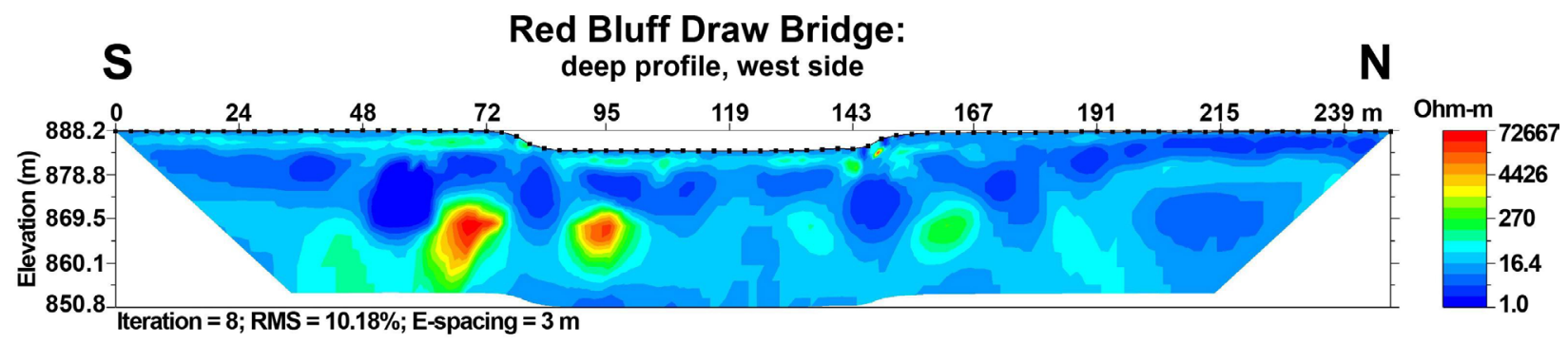

Figure 12. Deep profile, west side of Red Bluff Draw bridge.

surveys. The results of these surveys will guide NMDOT engineering decisions during the planning and construction phase of the highway realignment and possible bridge replacements.

All of these sites are located in areas where the gypsiferous Los Medaños Member of the Rustler Formation crops out or is present within one meter of the surface. This distribution of karst features is consistent with the soluble character of gypsum bedrock in the survey area, and suggests that additional karst features can be anticipated where the Los Medaños crops out beyond the mapped area of this study.

Most of the sinkholes in the study area are relatively shallow $(<3 \mathrm{~m})$. Resistivity surveys conducted adjacent to the sinkholes indicate that in most cases they do not have deep roots, rarely extending more than five meters below ground level. Given their widespread distribution in the study area, the shallow extent of most of the sinkholes detected during surface reconnaissance was surprising and unexpected. The limited vertical extent of these features probably results from the mixed lithology of soluble and insoluble bedrock (interbedded gypsum, mudstone and dolomite) in the Rustler Formation.

At some stations, longer-array electrical resistivity surveys identified high resistivity anomalies at greater depths. These features may represent void space, brecciated zones, or filled cavities in the underlying gypsum bedrock that do not breach the surface.

Variations in specific values of bedrock electrical resistivity were observed over the course of this investigation, particularly on the long array surveys with greater exploration depth (e.g., the Delaware River bridge surveys). This phenomenon may reflect lateral variations in bedrock weathering properties of the Los Medaños gypsum, resulting in variations in bedrock resistivity.

\section{References}

Bachman GO. 1980. Regional geology and Cenozoic history of Pecos region, southeastern New Mexico. US Geological Survey Open-File Report 80-1099, $116 \mathrm{p}$.

Bachman GO. 1987. Karst in evaporites in southeastern New Mexico. Sandia National Laboratories report SAND86-7078, 82 pages.

Cather SM. 2011. A north-flowing Miocene (?) ancestral Pecos River in southeastern New Mexico: A record of late Paleogene-early Miocene epeirogeny [abs.]: New Mexico Geological Society, Spring Meeting Proceedings Volume.

Hawley JW. 1993. Overview of the geomorphic history of the Carlsbad area. In: Love DW, Hawley JW, Kues BS, Austin GS, Lucas SG, editors. Carlsbad Region, New Mexico and West Texas. New Mexico Geological Society Fall Field Conference Guidebook 44, p.2-3.

Hendrickson GE, Jones RS. 1952. Geology and ground-water resources of Eddy County, New Mexico. New Mexico Bureau of Mines and Mineral Resources. Ground-Water Report 3.

Hiss WL. 1976. Structure of the Permian Ochoan Rustler Formation, southeast New Mexico and west Texas. United States Geological Survey Open-File Report 76-54.

Kelley VC. 1971. Geology of the Pecos country, southeastern New Mexico. New Mexico Bureau of Mines and Mineral Resources, Memoir 24.

Land L. 2013. Geophysical records of anthropogenic sinkhole formation in the Delaware Basin region, southeast New Mexico and west Texas, USA. Carbonates and Evaporites 28 (1-2): 183-190.

Land L, Veni G. 2012. Electrical resistivity surveys of anthropogenic karst phenomena, southeastern New Mexico. New Mexico Geology 34 (4): 117-125.

Land L, Asanidze L. 2015. Rollalong resistivity surveys reveal karstic paleotopography developed on near-surface gypsum bedrock. In: Doctor DH, Land L, Stephenson JB, editors. Proceedings of the Fourteenth Multidisciplinary Conference on 
Sinkholes and the Engineering and Environmental Impact of Karst, Rochester, Minnesota. National Cave and Karst Research Institute Symposium 5. Carlsbad (NM): National Cave and Karst Research Institute, p. 365-370.

NCKRI and NMBGMR. 2016. US Highway 285

Roadway Improvements 2016-17, Geotechnical Scoping Report, Geology and Karst Evaluation. Unpublished draft report to AMEC Foster Wheeler, December 14, 5 pages.

NCKRI and NMBGMR. 2017. US Highway 285

Roadway Improvements 2016-17, Geotechnical Scoping Report, Geology and Karst Evaluation, Regional Dissolution Features Literature Review. Unpublished draft report to AMEC Foster Wheeler, January 9, 4 pages.

Powers DW, Holt RM. 1993. The upper Cenozoic Gatuña Formation of southeastern New Mexico. In: Love DW, Hawley JW, Kues BS, Austin GS, Lucas SG, editors. Carlsbad Region, New Mexico and West Texas. New Mexico Geological Society Fall Field Conference Guidebook 44, p. 271-282.

Powers DW. 1997. The Los Medaños Member of the Permian (Ochoan) Rustler Formation. New Mexico Geology 21, p. 97-103.

Veni, G. 1999. A geomorphological strategy for conducting environmental impact assessments in karst areas. Geomorphology, 31: 151-180. Reprinted in: 2000. Proceedings of the 28th Binghamton Symposium: Changing the Face of the Earth-Engineering Geomorphology, J. Rick Giardino, Richard A. Marston, and Marie Morisawa (eds.), Elsevier Publishers, pp. 151180. 
368 NCKRI SYMPOSIUM 7 15TH SINKHOLE CONFERENCE 